\title{
EDITORIAL
}

\section{NEW NON-MILITARY RISKS}

The on-line version of the Dictionary of Standard Slovenian from 2000 defines the Slovenian equivalent of the term »risk « (tveganje) as the gerund of the verb "to risk" (tvegati). According to our secular understanding, the word is synonymous with the term "hazard" (nevarnost), which is in the same dictionary defined as the possibility of an accident, damage or something negative, generally unpleasant. In the title of this issue, we refer to the risks or hazards that are of non-military origin and at the same time new. A detailed description of the sources of threat, risk and hazard is given in the Resolution on National Security Strategy of the Republic of Slovenia adopted in 2010. According to Chapter 4 of the Resolution, the sources of threat and risk to the national security of the Republic of Slovenia, with regard to their origin, occur at the global, transnational and national levels. The global sources of threat and risk to national security include climate change, global financial, economic and social risks, as well as crisis areas. Transnational sources of threat and risk to national security include terrorism and illicit activities in the areas of conventional weapons, weapons of mass destruction and nuclear technology, organised crime, illegal migrations, cyber threats and misuse on information technologies and systems as well as activities of foreign intelligence services. Finally, national sources of threat and risk to national security include threats to public safety, natural and other disasters, the scarcity of natural resources and the degradation of the living environment, medical and epidemiological threats and other specific factors of uncertainty (which according to the resolution include poverty, negative demographic trends, vulnerability of critical infrastructure etc.)

This much about the sources of threat and risk to national security. But can we actually claim that these are new threats? Not really. Some of them are more recent, but not entirely new, again some other forms have appeared before in the near and distant past and might appear again in a more modern form very soon. Or they might not. Nevertheless, this does not mean that the authors of this issue have not prepared interesting aspects of possible risks or hazards. See for yourself. 
In the previous issue, Branimir Furlan, promised to provide the continuation of his article. In the second part of his article with the same title Ineffectiveness of the military as an indicator of inappropriate civilian control he thus says that the first part had presented the theoretical and methodological framework, while the second part presents the results of the study of civil-military relations in the Republic of Slovenia, focusing on the impact of civilian control on the effectiveness of the Slovenian Armed Forces. So, what are the results and how effective is the military according to the author?

Is the methodology of determining the leadership potential finally the way to excellent military leaders? is the title of the article by Dejan Okovič. He claims that after adopting the Methodology of Determining the Leadership Potential, the Slovenian Armed Forces will have all the necessary tools to introduce military leadership. He states that the social power provides leaders with the ability to lead their team members, while the latter are one of the prerequisites for the existence of leadership. In the article, the readers will find out what tools the author refers to, how to determine the leadership potential, and what leadership actually is.

The Arctic is subjected to climate changes, which are revealing its energy, political and economic potential, and are turning it into the new "Orient", says Sandra Martinič in her article titled Energy race for the arctic. The author explains what the Arctic actually is - land or sea, what are its energy potentials, who is interested in them and how they could be reached. The regulation of the access to energy resources by international law will most probably lead to even greater militarization of the area, since the security of resources and the environment will gain importance.

Foundering of the Austro-Hungarian flagship Viribus Unitis through Italian military archive files is the title of the article by Matjaž Bizjak. With the help of archival documents, the author takes the reader back to 1918 . To be precise, on 1 November 1918, two Italian commandos used an original method to founder the Austro-Hungarian flagship in Pula. Their idea was really something special and its implementation is exceptional. Just before the explosion, they were very surprised at the actual situation, but with the timer ticking, the time for improvisation was running out.

Anton Kanduti wrote an article titled Pilot project: military clubs in the Slovenian Armed Forces and a way ahead. He says that there are two military clubs in the Slovenian Armed Forces, namely one in the "Kadetnica" facility in Maribor and one in "Jernej Molan" barracks at Cerklje ob Krki. How do they operate, what are the legal bases for their operation, their purposes, and the aims they achieve? The article presents all of the above and the results of a survey among Slovenian Armed Forces members.

You are kindly invited to participate as readers and authors! 